\title{
STATE REGULATION IN FOREIGN ECONOMIC ACTIVITY OF CEMENT INDUSTRY OF UKRAINE
}

\author{
Tetiana TOPOLNYTSKA, Romana MATSKIV, Oleh YATSIUK, \\ Oksana SAVKO, Bohdan HRYVNAK \\ Ivano-Frankivsk National Technical University of Oil and Gas
}

\begin{abstract}
:
To specify the problems and priorities of state regulation of foreign economic activity (FEA) of cement industry enterprises of Ukraine, it is proposed to use the tool for assessing the state of FEA of cement industry enterprises, which is based on the expert method. The FEA development index of the cement industry is constructed with the usage of the method of expert assessments and analysis of the hierarchies of significance of each factor. Due to this, it was found that producers underestimate their own abilities to compete in foreign markets regarding the assortment structure, unsatisfactory financial condition, fierce competition and recession in foreign markets, especially traditional for Ukraine; unsatisfactory state policy of support of the development of the cement industry, in particular in terms of transparency of resource provision, assistance in updating the technical and technological base of the industry, the implementation of state infrastructure projects in Ukraine. On this basis, the priorities of state regulation of foreign economic activity of cement industry enterprises were determined by the following groups: sales, institutional and instrumental ones.
\end{abstract}

Key words: analytic hierarchy process, cement industry, foreign economic activity, state regulation

\section{INTRODUCTION}

The cement industry is one of the most important branches of industry in any country, regardless of its level of socio-economic development. It has a significant impact on all other industries and living conditions through the role of cement in the construction of production facilities, housing, industrial and social infrastructure.

Since the cement industry is one of the basic sectors of the economy, it is obvious that taking into account the characteristics, needs and limitations of the functioning of this industry can not be carried out on a general basis. If we consider the development of FEA of the cement industry of Ukraine, we can conclude that it is constrained by a number of factors, not at least the lack of specific government policy to develop the industry in general and stimulate the competitiveness of its products in foreign markets in particular. These considerations necessitate the formation of a special component of regulatory tools, which should be aimed at specific point problems of FEA in the industry and to increase the effectiveness of the mechanism of state regulation of FEA of cement companies of Ukraine.
In recent years, the demand for cement in Ukraine has been declining, and competition from foreign suppliers is increasing, which leads to the situation of limiting the domestic market, reducing of cement producers' income, deteriorating conditions of their technological development. As a solution to this problem, the classical liberal approach offers an increase in international operations that is the development of FEA. At the same time, the assessment of the share of cement exports in total production indicates a low degree of involvement of the industry in international economic relations and instability of the dynamics of export supplies [12]. Under these circumstances, the need to support the cement industry to ensure the development of the national economy as a whole, job creation and tax revenue in some regions of the country determines the need to review approaches to the development and implementation of the foreign economic policy in the context of Ukraine's cement industry. The main goal of this article is to determine the priorities of state regulation of FEA of enterprises of the cement industry of Ukraine. The need to achieve this goal necessitated the solution of the following tasks: 
- to analyze the main problems of FEA of cement industry enterprises of Ukraine and the shortcomings of the existing mechanism of its regulation;

- to suggest ways to increase the efficiency of foreign trade regulation mechanism of Ukrainian cement industry enterprises.

The object of research is the process of state regulation of FEA of enterprises of the cement industry of Ukraine under modern conditions. The subject of the research is scientific and practical aspects of development of measures of state regulation of FEA of enterprises of cement industry of Ukraine.

To identify and analyze the problems and priorities of state regulation of FEA of the enterprises of the cement industry of Ukraine, it is necessary to assess the state of their FEA. It should aslope determined how producers assess their own ability to compete in foreign markets taking into consideration the assortment structure, current financial situation, competition in foreign markets, especially traditional for Ukraine. The level of state policy of supporting the development of the cement industry, in particular in terms of transparency of resources, promoting the renewal of technical and technological base of the industry, implementation of state infrastructure projects in Ukraine must be evaluated and on this basis priority determinations of the state regulation in cement industry must be determined.

The most important results that indicate the relevance of the study are analytical support for identifying problems of functioning and development of FEA of the cement industry of Ukraine, which is based on a combination of statistical methods of quantitative data on industry development and expert assessment of macroeconomic trends. This will make it possible to identify the problems of the current mechanism for implementing regulatory policy and priorities for improving state regulation of FEA of enterprises in the cement industry of Ukraine.

\section{LITERATURE REVIEW}

In the world economic practice, there is no such definition as foreign economic activity, whereas the term "international business" is used, which means any activity in the field of private law, carried out by enterprises and aimed at profiting from the cooperation of economic entities of different countries [3]. Robert Grosse and Duane Kujawa's concept of international business includes "exports, imports, direct and portfolio investments, technology licensing, loans and international organizations" [16]. Daniels D. and Radeba Lee $\mathrm{H}$. characterize international business as "any business transactions carried out by two or more countries. Such business relationships can arise at the level of both private and public organizations. In the case of private companies' participation in international business, business transactions are carried out for profit" [8]. International operations are considered as a field of operational management' application in numerous works [5, 9, 11, 29].

The methodological apparatus of the foreign trade regulation mechanism consists of directions, methods, tools and levers, ways of their combination, and in the dynamic aspect, they are the sequence of implementation. Many scientific sources are devoted to the description and classification of these elements $[4,19,24]$, but among researchers there is no unity in their definition and list and it all depends on the established views of the author and the subject-object area, which he tries to cover in his own research.

Since the regulation of FEA is almost a general set of methods, in order to achieve the goals used appropriate regulatory tool which are specific means of influencing a particular lever. Attention to the instruments of foreign trade regulation has significantly increased with the intensification of integration and globalization processes, in particular in such aspects as economic and administrative measures to stimulate exports [20, 42], economic diplomacy and means of ensuring rights' protection of domestic subjects of FEA $[7,30,41]$, permitting proceedings in the field of protection of economic competition in FEA [28], currency regulation [40], customs regulation [18, 23, 39] and taxation of FEA [14, 35], responsibility for legislation' violation on FEA $[2,25]$, issues of permit regulation and technical barriers $[13,17,21]$.

Problems of state economic policy' institutional support are analyzed by M.M. Chanda, G. Bandyopadhyay and N. Banerjee [6]. According to S. Mosiuk and I. Mosiuk [26] this problems may cause the unsystematic and short-lived existence of individual institutions, lack of a state system and non-state bodies capable of interaction and coordination to effectively implement the tasks, inefficiency of realization of the corresponding vertical, horizontal and diagonal communications providing movement of necessary resources and processes.

It can also be added corruption as a means of lobbying certain interests contrary to the official state position and even common sense. In this sense, the position set out in the work of Douglass C. North [27] and developed by 0 . Demidyuk [10] regarding the importance of influence groups for the effectiveness of public policy is very productive. Important directions of such a policy according to G.J. Stigler are legislation aimed at regulating the redistribution of wealth among members of the society in a certain way [34], representatives of the legislature, in order to maintain their positions, so that to increase political support; stakeholders compete with each other, offering political support in exchange for enacting favorable legislation. Thus, government regulation will be carried out for stakeholders who are able to provide the necessary political support effectively and who will benefit more from the adoption of favorable legislation.

\section{METHODOLOGY}

It is expedient to carry out a comprehensive assessment of the state of FEA of cement industry enterprises by its representatives by an expert method. This method will allow to obtain representative results on the basis of sampling under the condition of a limited number of enterprises in the industry due to its oligopolistic structure. It is 
relatively easy to use as for time and complexity of collecting and processing information.

Factors influencing the state of FEA are grouped into five groups (Table 1, own elaboration based on [33]), taking into account the experience of forming the components of the Global Competitiveness Index [33]. These indicators were selected on the basis of Ukraine's rating according to the components of the Global Competitiveness Index. The analysis of the given data allows to define complexes of problems of regulatory character which act as an obstacle on a way of development of FEA of the enterprises in general and cement branch in particular. It should be noted that the grouping of these components was not carried out in accordance with their structure in the rating tables of the World Economic Forum, but to reflect the impact of the institutional environment on economic activity in general, foreign trade and investment.

It should be noted that the grouping of these components was carried out not in accordance with their structure in the rating tables of the World Economic Forum, but to reflect the impact of the institutional environment on economic activity in general, foreign trade and investment. The calculation of the integrated assessment in the form of FEA development index is carried out using the formula:

$$
I_{\mathrm{P}}=\sum_{j=1}^{n} X_{i j} \cdot a_{j} ; i=\{1, \ldots, 5\}
$$

$X_{\mathrm{ij}}$ is the assessment of experts in the areas of assessing the state of development of foreign economic activity in the industry $\left(1_{j}\right.$ is indicators of macroeconomic conditions; $2 \mathrm{j}$ is indicators of the impact of technical and technological base on foreign economic activity; $3 \mathrm{j}$ is indicators of regulatory impact; $4 \mathrm{j}$ is indicators of foreign economic conditions; $5_{j}$ is indicators of ability to compete in foreign markets; $a_{j}$ is the importance of each indicator).

The work on assessing knowledge about the importance of the components of FEA index $a_{j}$ should be done before the process of processing the survey results. Decisions made on the impact of relevant factors are auto-formalized, as they are made on the basis of expert knowledge. Therefore, the further task should be implemented using technologies for the implementation of complex formalized tasks, namely the analytic hierarchy process (AHP). The analytic hierarchy method, developed by Saaty, is a powerful multicriteria decision-making tool that has been used in numerous applications in various fields of economics, politics and engineering [22]. Recent approaches have combined AHP with other methods as presented by Byeong Seok Ahn [1].

Table 1

Grouping of factors influencing the state of FEA as a basis for its assessment

\begin{tabular}{|c|c|}
\hline Group & The content of influencing factors \\
\hline $\begin{array}{l}1 \text { Factors } \\
\text { of macroeconomic situation }\end{array}$ & $\begin{array}{l}\text { 1.1 The general economic situation in the country } \\
\text { 1.2 The state of domestic demand } \\
\text { 1.3 Favorable railway tariffs } \\
\text { 1.4 The level of the tax burden } \\
\text { 1.5 Availability of financial resources in the domestic market } \\
\text { 1.6 Exchange rate } \\
\text { 1.7 Dynamics of resource prices } \\
\text { 1.8 Potential for financing activities through public procurement } \\
\text { 2.1 Availability of raw materials of proper quality }\end{array}$ \\
\hline $\begin{array}{l}2 \text { Factors influencing } \\
\text { the technical } \\
\text { and technological base }\end{array}$ & $\begin{array}{l}\text { 2.2 Capacity utilization level } \\
\text { 2.3 The level of technological sufficiency of technological processes to ensure proper quality } \\
\text { 2.4 Efficiency of technological processes } \\
\text { 2.5 Prospects for updating the technical and technological base }\end{array}$ \\
\hline $\begin{array}{l}3 \text { Factors } \\
\text { of regulatory } \\
\text { and institutional influence }\end{array}$ & $\begin{array}{l}\text { 3.1 State of protection of property rights } \\
\text { 3.2 Level of protection against unfair competition in the market } \\
\text { 3.3 The impact of the military and political situation on business opportunities } \\
\text { 3.4 The state of non-tariff barriers in the domestic market } \\
\text { 3.5 Degree of introduction of technical standards } \\
\text { 3.6 The burden of state regulation in general and its administrative transparency }\end{array}$ \\
\hline $\begin{array}{l}4 \text { Factors } \\
\text { of foreign economic situation }\end{array}$ & $\begin{array}{l}\text { 4.1 The state of the world market } \\
\text { 4.2 The state of the current foreign markets } \\
\text { 4.3 Status of VAT refund in connection with export } \\
\text { 4.4 The burden of customs formalities } \\
\text { 4.5 The level of policy friendliness in current markets } \\
\text { 4.6 Prospects for foreign investment } \\
\text { 4.7 The state of non-tariff barriers in foreign markets }\end{array}$ \\
\hline $\begin{array}{l}5 \text { Factors } \\
\text { of internal capabilities }\end{array}$ & $\begin{array}{l}\text { 5.1 Adequacy of financial resources for foreign economic activity' implementation } \\
\text { 5.2 The level of current economic performance } \\
\text { 5.3 FEA prospects for specific enterprises } \\
\text { 5.4 The level of experience in foreign trade } \\
\text { 5.5 Willingness to change, innovate, take risks }\end{array}$ \\
\hline
\end{tabular}


AHP is the decomposition of the problem into increasingly simple components and further processing of the sequence of statements of the decision-maker, using pairwise comparisons. As a result, the relative degree of interaction in the hierarchy can be expressed. These statements are then expressed numerically. AHP includes procedures for synthesizing many statements, prioritizing criteria, and finding alternative solutions. It is important that the values obtained in this way are estimates in the scale of relations, but correspond to the so-called "hard" estimates [32].

Problem solving is a process of step-by-step setting of priorities. The first stage identifies the most important elements of the problem, the second - the best way to verify the statements and evaluate the elements. The whole process is subject to review and rethinking until it is established that all important problem-solving characteristics are covered.

Thus, the first step of AHP is to decompose and present the problem in a hierarchical form. Dominant hierarchies are considered, which are built from the top (goal - from the point of view of management) through intermediate levels (criteria on which the following levels depend) to the lowest level, which is usually a list of alternatives. A hierarchy is considered complete if each element of a given level functions as a criterion for all elements of a level below. That is, the hierarchy can be divided into subhierarchies that share the highest element. The law of hierarchical continuity requires that the elements of the lower level are equalized in pairs relative to the elements of the next level and so on to the top of the hierarchy.

The sequence of actions to assess the importance of the components of FEA development index should be implemented as follows:

1. Consideration of a finite set of alternatives $X=\left\{x_{1}, \ldots x_{m}\right\}$. When comparing arbitrary two elements $x_{i}$ and $x_{j}$ of this set, the subject of evaluation is asked the question: to what extent (how many times) does one element prevail over another? A scale of relative importance of objects according to Saati $[31,32]$ is used to determine the preferences of subjects (Table 2, own compilation based on [31, p. $86 ; 32$, p. 257]).

Table 2 Scale of preferences of experts

\begin{tabular}{lc}
\hline \multicolumn{1}{c}{ Definition } & Intensity of importance \\
\hline Equal importance & 1 \\
Moderate importance & 3 \\
Strong importance & 5 \\
Very strong importance & 7 \\
Extreme importance & 9 \\
Intermediate judgments & $2,4,6,8$ \\
\hline
\end{tabular}

2. Creating a matrix of pairwise comparisons of indicators included in the components of FEA development index based on the results of the surveys. If the answers were agreed, then $a_{i j}=\frac{w_{i}}{w_{j}}$ for everyone $i, j=\overline{1, m}$.
In case of full agreement $A\left(\begin{array}{c}w_{1} \\ \ldots \\ w_{m}\end{array}\right)=m\left(\begin{array}{c}w_{1} \\ \ldots \\ w_{m}\end{array}\right)$. So the vector of relative values $\left(\begin{array}{c}w_{1} \\ \ldots \\ w_{m}\end{array}\right)$ is an eigenvector of the matrix

Aand corresponds to the eigenvalue $\lambda=m$ of this matrix.

3. Calculation of the vector of relative values $\left(w_{1}, \ldots w_{m}\right)^{\top}$ using the method of geometric mean:

$$
w_{i}=\frac{\sqrt[m]{a_{11} \cdot \ldots \cdot a_{i m}}}{\sum_{i=1}^{m} \sqrt[m]{a_{i 1} \cdot \ldots \cdot a_{i m}}}
$$

4. Estimation of the eigenvalue, which corresponds to the calculated vector of relative values:

$$
\lambda=\frac{1}{m} \lambda_{i}
$$

where:

$\lambda_{i}$ is calculated as a result component-by-component division of multiplication components $A w$ on components of relative values vector.

5. Calculation of the consistency index:

$$
I_{\mathrm{y}}=\frac{\lambda-m}{m-1}
$$

The value of this index should be comparable to the reference (Table 3, own compilation based on [38]), in particu$\operatorname{lar} l_{y} \leq 0.1 l_{e}$, if the results of the expert survey are satisfactory (critical value of the difference of $20 \%$ ).

Table 3

Reference values of the consistency index

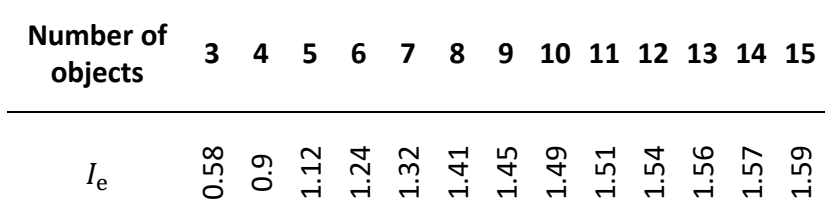

The results of pairwise comparisons of indicators that are part of the index of development of foreign economic activity are summarized in Table 4.

Table 4 Numerical estimates of relative value vectors

\begin{tabular}{cccccc}
\hline \multirow{2}{*}{ Values } & \multicolumn{5}{c}{ Relative values vector } \\
\cline { 2 - 6 } & $\mathbf{1 . X}$ & $\mathbf{2 . X}$ & $\mathbf{3 . X}$ & $\mathbf{4 . X}$ & $\mathbf{5 . X}$ \\
\hline X.1 & 0.15 & 0.16 & 0.18 & 0.10 & 0.43 \\
X.2 & 0.23 & 0.09 & 0.05 & 0.35 & 0.26 \\
X.3 & 0.19 & 0.21 & 0.12 & 0.07 & 0.05 \\
X.4 & 0.08 & 0.39 & 0.12 & 0.05 & 0.11 \\
X.5 & 0.17 & 0.15 & 0.31 & 0.24 & 0.15 \\
X.5 & 0.04 & - & 0.21 & 0.09 & - \\
X.7 & 0.07 & - & - & 0.10 & - \\
X.8 & 0.08 & - & - & - & - \\
\hline
\end{tabular}

6. Carrying out similar procedures for the components of the second level of FEA development index (5 of them) and determining the vector of relative values for these components $\left(u_{1}, \ldots u_{k}\right)^{T}$ has the following results $(0.174$; 0.216 ; $0.199 ; 0.216 ; 0.195)$. 
7. The obtained values of the vector of relative values for the components of the index of development of FEA are weight values for the values of the relative values of the indicators that form each component. This allows to estimate the weight of each indicator in the index $\left(w_{i}^{I}\right)$ :

$$
w_{i}^{I}=\left(w_{1}, \ldots w_{m}\right) \cdot u_{i}
$$

Thus, we can get an effective table of the weight of each indicator when estimating the FEA development index (Table 5).

Table 5

Weight values of indicators that form the FEA development

index

\begin{tabular}{cc}
\hline The content of influencing factors & $\begin{array}{c}\text { Weight } \\
\text { of factor }\end{array}$ \\
\hline
\end{tabular}

1.1 The general economic situation in the country $\quad 0.026$

1.2 The state of domestic demand $\quad 0.040$

1.3 Favourable railway tariffs

0.032

1.4 The level of the tax burden

0.013

1.5 Availability of financial resources in the domestic market

0.030

1.6 Exchange rate

0.007

1.7 Dynamics of resource prices

0.011

1.8 Potential for financing activities through public procurement

2.1 Availability of raw materials of proper quality

0.014

2.2 Capacity utilization level

0.034

0.020

2.3 The level of technological sufficiency of techno-

logical processes to ensure proper quality

2.4 Efficiency of technological processes

0.046

2.5 Prospects for updating the technical and technological base

3.1 State of protection of property rights

3.2 Level of protection against unfair competition in the market

3.3 The impact of the military and political situation on business opportunities

3.4 The state of non-tariff barriers in the domestic market

3.5 Degree of introduction of technical standards

3.6 The burden of state regulation in general and its administrative transparency

4.1 The state of the world market

4.2 The state of the current foreign markets

4.3 Status of VAT refund in connection with export

4.4 The burden of customs formalities

0.084

0.032

0.037

0.009

0.025

0.025

0.062

0.042

0.021

0.076

0.016

0.010

4.5 The level of policy friendliness in current markets

4.6 Prospects for foreign investment

0.051

0.021

4.7 The state of non-tariff barriers in foreign markets

5.1 Adequacy of financial resources for the implementation of foreign economic activity

5.2 The level of current economic performance

5.3 FEA prospects for specific enterprises

5.4 The level of experience in foreign trade

5.5 Willingness to change, innovate, take risks
For each factor each expert gave an answer on the degree of positive impact on the state of foreign trade in the industry on a 10-point scale. Commercial directors (deputy directors for economics) and heads of foreign economic activity services of 9 Ukrainian cement companies were selected as experts.

The degree of agreement of experts is assessed using the Kendall concordance coefficient:

$$
W=\frac{12 \cdot S}{n^{2} \cdot\left(m^{3}-m\right)}
$$

where:

$S$ is the sum of the squares of the deviations of the sum of the ranks of each object of examination from the arithmetic mean; nis the number of experts; mis the number of examination objects.

Depending on the degree of agreement of the experts' opinions, the concordance coefficient can take values from 0 (in the absence of agreement) to 1 (with complete unanimity). At $0.4 \leq 0.6$ the quality of the assessment is considered satisfactory.

In order to ensure the comparability of indicators, it is advisable to normalize them. Since there is a question about the positivity of the influence of a factor for the indicators, the maximum value of which is considered the best, the rationing is carried out using the formula:

$$
X=\frac{X_{i}-X_{\min }}{X_{\max }-X_{\min }}
$$

where:

$X$ is the normalized indicator;

$X_{\mathrm{i}}$ is average (actual) value of the indicator;

$X_{\max }$ is the maximum possible value of the indicator;

$X_{\min }$ is the minimum possible value of the indicator.

Normalized indicators meet the requirements of dimension lessness, the total starting point of all indicators, the only interval of change.

\section{RESULTS}

\section{Cement Industry of Ukraine}

Today, Ukraine has a fairly strong cement industry, which is represented by a number of manufacturing enterprises. In 2019, 9 companies produced cement in Ukraine: Dyckerhoff Cement Ukraine PrJSC (subsidiaries Volyncement and Yugcement), Heidelbergcement Ukraine PrJSC (Kryvyi Rih Plant and Kamyanskyi Plant), EurocementUkraine PrJSC, Ivano-Frankivskcement PrJSC, Podilskyi Cement PJSC, Mykolaiv PrJSC, Cement LLC. In the course of economic transformations, the cement industry has faced a number of problems related to the peculiarities of economic management in the industry, the problems of the dynamics of macroeconomic and market conditions, political events.

If we analyze the development and current state of the cement industry in Ukraine, we can identify the following features of economic activity in the industry that affect the financial results and competitiveness in domestic and foreign markets:

1. Cement production is the branch of one product that is there are only a few classes of cement and clinker as 
a basis for its production, and therefore the main element of sales policy of enterprises in the industry is the price of products and their quality.

2. Cement production in terms of the number of sellers in the market is oligopolized due to the presence of objective barriers - the need for large investments in the creation and modernization of production, the cost of the production itself and a significant payback period.

3. Dominance of foreign capital in the ownership structure of cement enterprises of Ukraine: Ukrainian company Ivano-Frankivskcement PrJSC and four international corporations: CRH Ukraine, Heidelbergcement Ukraine PrJSC, Dyckerhoff Cement Ukraine PrJSC, Eurocement-Ukraine PrJSC.

4. Dependence of the enterprises of the branch on resource provision, at the same time as a result of military actions a part of raw material base and production capacities on the territory of the Joint Forces Operation and in the Autonomous Republic of Crimea were lost.

5. One of the important problems of the industry is the shadow segment - in the Ukrainian market there is counterfeit and low-quality cement, which affects not only producers who do not make a profit, the state that does not make taxes, but also consumers who receive low-quality products and, consequently, incur additional costs.

6. Geopolitical conflict has a significant impact on the dynamics of the industry's production volumes, as three plants are located in the occupied territory (Promcement LLC, Amvrosiyivsky Plant of PJSC Heidelbergcement Ukraine, PJSC Bakhchisaray Plant Budindustriya, Autonomous Republic of Crimea).

The dynamics of the volume of the cement market in Ukraine in 2018-2019 in physical and monetary terms are presented in Table 6 (own elaboration based on the data of Ukrcement).

Table 6

Dynamics of cement market volume in Ukraine in 2018-2019

\begin{tabular}{|c|c|c|c|}
\hline Indicator & 2018 & 2019 & Growth, \% \\
\hline $\begin{array}{l}\text { Production in real terms, thousand } \\
\text { tons }\end{array}$ & 9307.4 & 9191.7 & $-1.2 \%$ \\
\hline Export in real terms, thousand tons & 270.5 & 483.9 & $78.9 \%$ \\
\hline Import in real terms, thousand tons & 445.5 & 475.9 & $6.8 \%$ \\
\hline $\begin{array}{l}\text { Market volume in real terms, thou- } \\
\text { sand tons }\end{array}$ & 9444.8 & 9162.4 & $-3.0 \%$ \\
\hline $\begin{array}{l}\text { Production in monetary terms, bil- } \\
\text { lion UAH }\end{array}$ & 12.05 & 13.18 & $9.4 \%$ \\
\hline $\begin{array}{l}\text { Export in monetary terms, billion } \\
\text { UAH }\end{array}$ & 0.28 & 0.55 & $92.6 \%$ \\
\hline $\begin{array}{l}\text { Import in monetary terms, billion } \\
\text { UAH }\end{array}$ & 0.60 & 0.69 & $13.9 \%$ \\
\hline $\begin{array}{l}\text { Market volume in monetary terms, } \\
\text { billion UAH }\end{array}$ & 12.37 & 13.32 & $7.7 \%$ \\
\hline
\end{tabular}

The volume of the cement market in 2019 decreased by $3 \%$ in physical terms. A slight decrease in production together with a significant increase in exports led to a decrease in cement' amount in the domestic market by 282 thousand tons. In monetary terms, the market volume, on the other hand, increased by $7.7 \%$. Due to the increase in the cost of cement, the growth was demonstrated by all market indicators, including production. The most significant rate was exported, the value of which almost doubled. In general, after 2015, the cement market shows a tendency of recovery, which is associated with the volume of construction work and investment activity in the industry and infrastructure.

Cement production, similar to cement clinker production, decreased until 2015. The increase began in 2016, but this tendency was unstable: cement production in 2019 decreased by 116 thousand tons compared to 2018 . The cost growth and cement market value led to a simultaneous growth of production in monetary terms by $9 \%$ (Figure 1, own elaboration based on the data of Ukrcement).

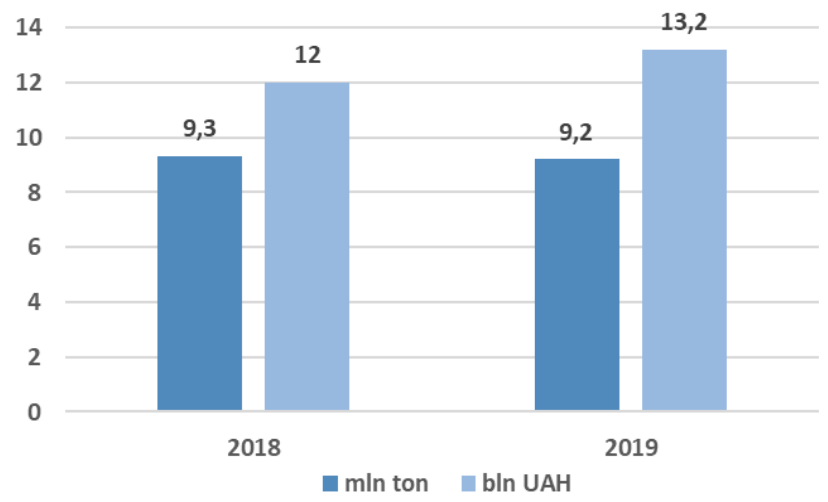

Fig. 1 Cement production in Ukraine in 2018-2019, in real and monetary terms, million tons and billion UAH

Thus, cement production currently does not have a stable tendency, changing under the influence of internal (cost growth, logistics, demand change) and external factors (competition from importers, supply prices in foreign markets, demand for Ukrainian products from other countries). At the same time, due to rising production costs, the money supply of cement is constantly growing.

Considering specifically the foreign economic activity of enterprises, it is worth paying attention to certain features.

In 2019, the growth tendency of cement exports continued, compared to 2018 , deliveries increased by $78.9 \%$ in physical terms and by $92.6 \%$ in monetary terms (Table 6 ). In fact, the entire volume of exports is made up of ordinary cements, and white, alumina, slag and hydraulic cements accounted for 0.1-0.2\% in 2018-2019 (Table 7, own elaboration based on the data of Ukrcement). 
Table 7

Export of cement from Ukraine in 2018-2019 by types, in kind and in money terms, thousand tons, thousand USD

\begin{tabular}{|c|c|c|c|c|}
\hline \multirow[b]{3}{*}{$\begin{array}{c}\text { Type } \\
\text { of products }\end{array}$} & \multicolumn{4}{|c|}{ Volume } \\
\hline & \multicolumn{2}{|c|}{2018} & \multicolumn{2}{|c|}{2019} \\
\hline & 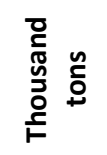 & 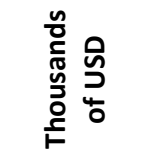 & 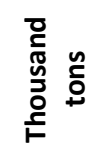 & 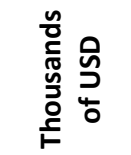 \\
\hline Regular cements & 269.95 & 10638.63 & 483.69 & 20131.18 \\
\hline White cements & 0.36 & 59.26 & 0.24 & 44.70 \\
\hline Alumina cements & 0.17 & 48.97 & 0.01 & 4.54 \\
\hline $\begin{array}{l}\text { Slag, hydraulic } \\
\text { cements }\end{array}$ & 0.01 & 8.78 & 0.00 & 1.12 \\
\hline Total & 270.49 & 10755.63 & 483.94 & 20181.54 \\
\hline
\end{tabular}

The high growth rates of exports in 2019 indicate the presence of untapped prospects for consumption in the foreign market, the mastery of which is accompanied by legal and economic barriers.

Over the last five years, cement exports from Ukraine have had significant annual differences in volumes, as they are small and depend on individual agreements with consumers. The share of exports in production has been growing recently, for example, in 2019 it increased by 2.4 percentage points compared to 2018, but still occupies about $5 \%$ (Figure 2, own elaboration based on the data of Ukrcement).
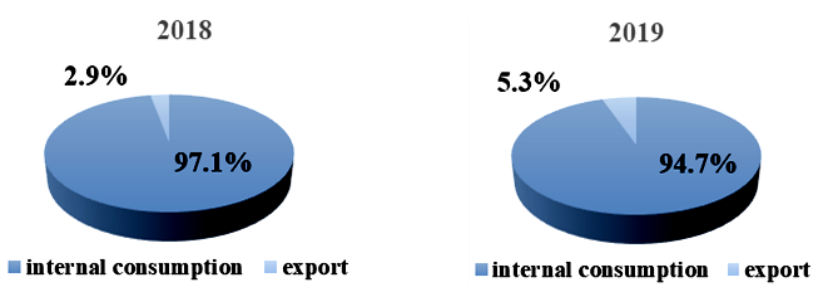

Fig. 2 Share of export in cement production in Ukraine in 2018 2019, in kind, \%

Ukraine exports cements to a limited number of countries, all of which are relatively short. The largest volumes are sent to Romania, Hungary and Belarus - in 2019, exports in these areas amounted to 419 thousand tons, $84 \%$ more than in 2018. Slovakia became a new direction of export, in 20194.7 thousand tons of products were sent there (Table 8, own elaboration based on the data of Ukrcement).

The geography of exports is dependent on trade restrictions due to conflicts of interest and measures to protect domestic markets. Thus, Russia has disappeared from the list of consumer countries. Exports to other countries vary depending on the conditions of certification, quotas and duties accepted or may be accepted, possible antidumping investigations, during which supplies are suspended, and so on. Deliveries to EU countries are also limited by the need to be certified for each batch of cement due to the lack of a laboratory to check the quality of cement. Currently, companies are either tested in a European laboratory or invite specialists to Ukraine. And only after that they get the right to export.
Table 8

Cement export from Ukraine in 2018-2019 by recipient countries, in kind and in monetary terms, thousand tons,

thousand USD

\begin{tabular}{|c|c|c|c|c|}
\hline \multirow[b]{3}{*}{ Country } & \multicolumn{4}{|c|}{ Volume } \\
\hline & \multicolumn{2}{|c|}{2018} & \multicolumn{2}{|c|}{2019} \\
\hline & 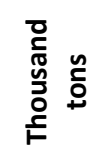 & 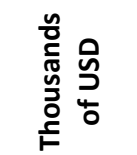 & 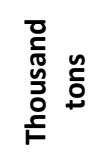 & 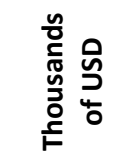 \\
\hline Romania & 109.99 & 4174.62 & 145.45 & 5621.78 \\
\hline Hungary & 63.12 & 2079.98 & 141.82 & 4744.13 \\
\hline Belarus & 55.22 & 2691.33 & 132.02 & 6867.40 \\
\hline Moldova & 36.80 & 1464.24 & 48.28 & 2127.23 \\
\hline Poland & 4.81 & 227.73 & 11.32 & 538.25 \\
\hline Slovakia & - & - & 4.67 & 224.83 \\
\hline Other & 0.55 & 117.72 & 0.38 & 57.92 \\
\hline Total & 270.49 & 10755.63 & 483.94 & 20181.54 \\
\hline
\end{tabular}

Ukraine's cement imports in 2019 increased in physical terms by almost 7\% (Figure 3, own elaboration based on the data of Ukrcement).

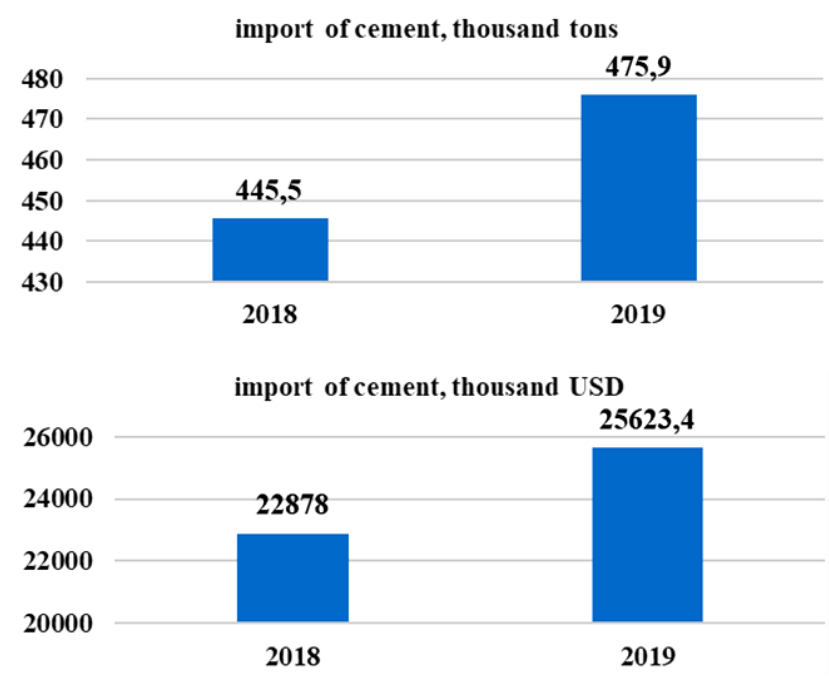

Fig. 3 Import of cement in Ukraine in 2018-2019, in kind and in money terms, thousand tons, thousand USD

This was a continuation of the sharp increase in deliveries that occurred in 2018. In 2018, cement imports increased almost 10 times compared to the previous year. This increase in cement imports is only partly due to the abolition of additional import duties and a reduction in the import duty rate on goods produced in the European Union, and most of all - the activity of Belarusian producers who supply products at low prices. The growing dynamics of imports indicates an increase in competition from foreign producers, which reduces sales of Ukrainian enterprises within the country.

Belarus has been the leader in imports in recent years (Table 9, own elaboration based on the data of Ukrcement). In 2019 , it accounted for $57 \%$ of natural imports. At the same time, its share in the monetary volume of imports is $46 \%$. This indicates that the cost of these deliveries is lower than average. 
Table 9

Import of cement in Ukraine in 2018-2019 as per countriessenders, in kind and in money terms, thousand tons, thousand US dollars

\begin{tabular}{|c|c|c|c|c|}
\hline \multirow{3}{*}{ Country } & \multicolumn{4}{|c|}{ Volume } \\
\hline & \multicolumn{2}{|c|}{2018} & \multicolumn{2}{|c|}{2019} \\
\hline & 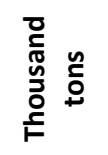 & 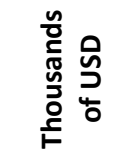 & 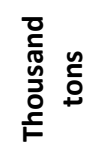 & 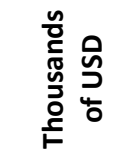 \\
\hline Belarus & 360.47 & 14495.53 & 270.70 & 11758.59 \\
\hline Moldova & 44.04 & 2092.91 & 157.89 & 7898.01 \\
\hline Turkey & 31.91 & 3632.08 & 20.95 & 2436.97 \\
\hline Russian Federation & - & - & 16.13 & 758.11 \\
\hline Egypt & 4.50 & 510.19 & 6.00 & 644.10 \\
\hline Slovakia & 1.34 & 200.59 & - & - \\
\hline Other & 3.26 & 1946.69 & 4.28 & 2127.62 \\
\hline Total & 445.53 & 22877.98 & 475.94 & 25623.39 \\
\hline
\end{tabular}

In 2013, the main importer of cement to Ukraine was Turkey, and in 2019 it accounted for only 4.4\% (by volume). The second largest destination after Belarus is Moldova. Ukraine is a strategic market for Moldovan cement producers, so they seek to occupy a permanent niche in local consumption.

After the complete absence of imports from the Russian Federation in 2018, in 2019, 16 thousand tons of cement were delivered, which amounted to $3.4 \%$ of the natural volume of imports. Further deliveries in this area will depend on trade restrictions that may be imposed by both sides.

Therefore, we can see that thanks to the available raw material base and production capacity, Ukraine is able to provide itself with cement. The share of imported products in the market is about 5\%. However, until 2018, cement imports amounted to less than $1 \%$, which indicates the activity of producers in neighboring countries to develop the Ukrainian market. Investments in the building materials industry, in particular in Belarus and Moldova, increase the production capacity of cement plants and increase competition in the domestic market of Ukraine by importers.

Institutional factors have a significant impact on the forms, methods and results of foreign economic activity. Analysis of the quality of the institutional environment of Ukraine allowed to identify both positive and negative phenomena in the dynamics of the conditions of economic activity. On this basis, a set of regulatory problems is identified, which are an obstacle to the development of foreign economic activity of enterprises in general and the cement industry in particular. They are presented in Table 10 in a grouped form. The basis of grouping is a sign of the specificity of these problems for the cement industry [37]. The identified features of economic activity, trends in foreign trade and regulatory problems necessitate the definition of priorities for state regulation of foreign trade in the cement industry on the basis of a comprehensive assessment of its condition by industry representatives.

\section{Determination of FEA development index of cement in- dustry}

The results of the calculations are presented in Table 11. Analysis of the answers of experts by groups of indicators shows that producers underestimate their own ability to compete in foreign markets regarding the assortment structure, unsatisfactory financial condition, fierce competition and recession in foreign markets, especially traditional for Ukraine. In addition, rather negative characteristics were given to the state policy to support the development of the cement industry, including tariff policy, transparency of resource provision, assistance in updating the technical and technological base of the industry, the implementation of state infrastructure projects in Ukraine.

Table 10

Regulatory problems that hinder the development of enterprises FEA of the Ukrainian cement industry

\begin{tabular}{|c|c|}
\hline General & Specific \\
\hline $\begin{array}{l}\text { - low level of property rights protection; } \\
\text { - corruption and clientelistic access to power } \\
\text { lead to a high level of voluntarism and favour- } \\
\text { itism of officials in making regulatory deci- } \\
\text { sions; } \\
\text { - a significant amount of illegal payments for } \\
\text { obtaining permits, customs clearance, etc.; } \\
\text { - the existence of the practice of determining } \\
\text { the "tax burden"; } \\
\text { - appealing against regulatory norms and reg- } \\
\text { ulatory decisions is difficult; } \\
\text { - deterioration of corporate governance qual- } \\
\text { ity; } \\
\text { - underdevelopment of stock market institu- } \\
\text { tions. }\end{array}$ & $\begin{array}{l}\text { - lack of motivation to increase investments in the renewal of cement production } \\
\text { for foreign investors; } \\
\text { - military-political events have a significant impact on the dynamics of production } \\
\text { volumes, in particular due to the loss } \\
\text { of capacity and raw material base } \\
\text { in the area of environmental protection and the Autonomous Republic of Crimea; } \\
\text { - lack of effective measures to protect } \\
\text { the domestic cement market from dumped imports; } \\
\text { - delaying the process of implementing the program of construction of roads with } \\
\text { cement-concrete pavement; } \\
\text { - unreliable control over counterfeiting; } \\
\text { - lack of special attention } \\
\text { to the development of the cement industry in general and the stimulation of foreign } \\
\text { economic activity } \\
\text { of its enterprises in particular. }\end{array}$ \\
\hline
\end{tabular}


Table 11

The results of the assessment of the index of development of foreign economic activity

Factor

1.1 The general economic situation in the country

1.2 The state of domestic demand

1.3 Favourable railway tariffs

1.4 The level of the tax burden

1.5 Availability of financial resources in the domestic market

1.6 Exchange rate

1.7 Dynamics of resource prices

1.8 Potential for financing activities through public procurement

The result of component 1

2.1 Availability of raw materials of proper quality

2.2 Capacity utilization level

2.3 The level of technological sufficiency of technological processes

to ensure proper quality

2.4 Efficiency of technological processes

2.5 Prospects for updating the technical and technological base

The result of component 2

3.1 State of protection of property rights

3.2 Level of protection against unfair competition in the market

3.3 The impact of the military and political situation on business opportunities

3.4 The state of non-tariff barriers in the domestic market

3.5 Degree of introduction of technical standards

3.6 The burden of regulation and its administrative transparency

The result of component 3

4.1 The state of the world market

4.2 The state of the current foreign markets

4.3 Status of VAT refund in connection with export

4.4 The burden of customs formalities

4.5 The level of policy friendliness in current markets

4.6 Prospects for foreign investment

4.7 The state of non-tariff barriers in foreign markets

The result of component 4

5.1 Adequacy of financial resources for the implementation of foreign economic activity

5.2 The level of current economic performance

5.3 FEA prospects for specific enterprises

5.4 The level of experience in FEA

5.5 Willingness to change, innovate, take risks

\begin{tabular}{ccccc} 
Weight & $\mathbf{2 0 1 6}$ & $\mathbf{2 0 1 7}$ & $\mathbf{2 0 1 8}$ & $\mathbf{2 0 1 9}$ \\
\hline 0.026 & 0.49 & 0.68 & 0.71 & 0.58
\end{tabular}

$\begin{array}{lllll}0.040 & 0.63 & 0.63 & 0.68 & 0.62\end{array}$

$\begin{array}{lllll}0.032 & 0.64 & 0.42 & 0.66 & 0.38\end{array}$

$\begin{array}{lllll}0.013 & 0.39 & 0.54 & 0.51 & 0.52\end{array}$

$\begin{array}{lllll}0.030 & 0.60 & 0.53 & 0.49 & 0.43 \\ 0.007 & 0.80 & 0.66 & 0.71 & 0.58\end{array}$

$\begin{array}{lllll}0.011 & 0.64 & 0.68 & 0.42 & 0.64\end{array}$

$\begin{array}{lllll}0.014 & 0.63 & 0.70 & 0.71 & 0.68\end{array}$

$\begin{array}{lcccc} & \mathbf{0 . 1 0 4} & \mathbf{0 . 1 0 2} & \mathbf{0 . 1 0 8} & \mathbf{0 . 0 9 3} \\ 0.034 & 0.71 & 0.71 & 0.73 & 0.74\end{array}$

$\begin{array}{lllll}0.020 & 0.60 & 0.60 & 0.70 & 0.53\end{array}$

$\begin{array}{lllll}0.046 & 0.46 & 0.46 & 0.51 & 0.62\end{array}$

$\begin{array}{lllll}0.084 & 0.47 & 0.47 & 0.57 & 0.48\end{array}$

$\begin{array}{lllll}0.032 & 0.54 & 0.54 & 0.49 & 0.48\end{array}$

$\begin{array}{lllll}0.114 & 0.114 & 0.126 & 0.120\end{array}$

$\begin{array}{lllll}0.037 & 0.50 & 0.54 & 0.46 & 0.56\end{array}$

$\begin{array}{llllll}0.009 & 0.34 & 0.34 & 0.48 & 0.36\end{array}$

$\begin{array}{lllll}0.025 & 0.78 & 0.76 & 0.79 & 0.54\end{array}$

$\begin{array}{lllll}0.025 & 0.58 & 0.66 & 0.69 & 0.70\end{array}$

$\begin{array}{lllll}0.062 & 0.49 & 0.58 & 0.54 & 0.67\end{array}$

$\begin{array}{lllll}0.042 & 0.64 & 0.66 & 0.69 & 0.60\end{array}$

$\begin{array}{lllll}0.113 & 0.121 & 0.120 & 0.121\end{array}$

$\begin{array}{llllll}0.021 & 0.70 & 0.74 & 0.72 & 0.68\end{array}$

$\begin{array}{lllll}0.076 & 0.69 & 0.72 & 0.72 & 0.47\end{array}$

$\begin{array}{lllll}0.016 & 0.43 & 0.41 & 0.38 & 0.40\end{array}$

$\begin{array}{lllll}0.010 & 0.38 & 0.39 & 0.42 & 0.63\end{array}$

$\begin{array}{lllll}0.051 & 0.60 & 0.63 & 0.54 & 0.54\end{array}$

$\begin{array}{lllll}0.021 & 0.61 & 0.60 & 0.64 & 0.51\end{array}$

$\begin{array}{lllll}0.022 & 0.60 & 0.66 & 0.69 & 0.66\end{array}$

$\begin{array}{cccc}0.60 & 0.66 & 0.69 & 0.66 \\ 0.134 & 0.140 & 0.136 & 0.115\end{array}$

$\begin{array}{lllll}0.083 & 0.60 & 0.69 & 0.48 & 0.61\end{array}$

$\begin{array}{lllll}0.051 & 0.50 & 0.43 & 0.56 & 0.44\end{array}$

$\begin{array}{llllll}0.011 & 0.67 & 0.68 & 0.70 & 0.59\end{array}$

$\begin{array}{lllll}0.022 & 0.73 & 0.77 & 0.78 & 0.62\end{array}$

The result of component 5

$\begin{array}{lllll}0.028 & 0.67 & 0.67 & 0.73 & 0.68\end{array}$

FEA development index

$\begin{array}{llll}0.117 & 0.122 & 0.113 & 0.112\end{array}$

As Figure 4 shows, the best year for the cement industry was 2018, but the aggravation of the financial situation and military and political events led to a significant deterioration in the state of FEA.

The main problem for Ukrainian cement producers was the rapid increase in imports from neighboring countries. The worst year in terms of imports for Ukrainian cement producers was 2018. Belarus has increased cement exports to Ukraine 52 times, and Russia has almost doubled its clinker exports. In 2019, the total volume of imports was further dominated by cement from Belarus, as well as from Moldova, which increased imports to Ukraine almost 4 times.

Such an increase in cement imports to Ukraine did not always follow market rules. There were cases of both dumping and state subsidies. The Ukrainian producer was forced to compete with cement importers from countries where production is subsidized by the state (Belarus) or stimulated by "political" energy prices (Russia and Moldovan Transnistria).

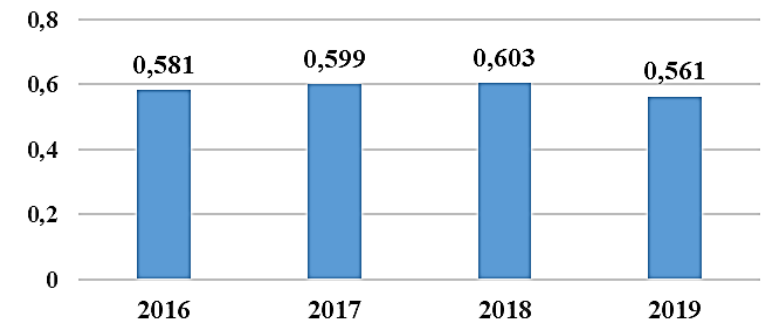

Fig. 4 Dynamics of FEA development index

That is why companies operating in the cement market in Ukraine have initiated an anti-dumping investigation. In 2019, the Interdepartmental Commission on International Trade under the Ministry of Economic Development and Trade of Ukraine established the existence of cement products' dumped imports from Russia, Belarus and Moldova during 2015-2018 and decided to impose anti-dumping duties.

Anti-dumping duties to these countries will be applied for 5 years in the following amounts:

a) $114.95 \%$ of goods originating from the Russian Federation; 
b) $57.03 \%$ of the goods originating from the Republic of Belarus;

c) $94.46 \%$ of the goods originating from the Republic of Moldova.

The biggest risk of effective measures' lack to protect domestic production in the Ukrainian market is that by stimulating dumped imports, the country may lose strategic investors who are already present in Ukraine and intend to invest heavily in the cement industry. A recent example of this risk reality was the decision of the Heidelbergcement Group, adopted in late 2018, on the eve of the introduction of anti-dumping duties, to sell assets in Ukraine and redirect investments to other markets. Withdrawal from the Ukrainian market of the world's second largest cement company was a significant reputational loss for the cement industry and the economy as a whole. This is the second exit from the market of a large international cement company after the Lafarge group withdrew its investments from Ukraine in 2013.

As for exports, its share in total cement production in 2019 was about $5 \%$. This is a small amount, but it should be kept in mind that four out of five players in the Ukrainian market are international companies that have their plants around the world. It is often unprofitable for them to export cement from Ukraine and compete with their own plants in other countries. In addition, despite favorable prices for exports to Europe, Ukraine has complex logistics to deliver goods to consumers: there are no transshipment stations either by rail or in seaports. The construction of logistics centers in the port and on the border with the EU could give impetus to a strong increase in exports.

Per capita cement consumption per year in Ukraine is the lowest among neighboring countries and is critically low compared to fast-growing countries. According to the study The Global Cement Report 2020, this figure in 2018 in Ukraine was $226 \mathrm{~kg}$, while in Belarus - $358 \mathrm{~kg}$, Russia $367 \mathrm{~kg}$, Poland $-485 \mathrm{~kg}$, Turkey $-835 \mathrm{~kg}$, and in China $1555 \mathrm{~kg}$ per year [36].

The cement industry continues to need government support: assistance to modernize enterprises, tax breaks for reconstruction, projects and grants. On the other hand, state-supported producers will be required to guarantee job growth and no unjustified increase in cement prices.

\section{DISCUSSION AND CONCLUSIONS}

The state does not regulate a single industry, but their totality in the national economy, ensuring a certain proportionality of each industry's contribution to GDP, employment, tax revenues and so on [15, p. 313]. With the view of this, the needs or features of each specific sector in the formation of state socio-economic policy in any case will not be fully taken into account. Taking into account the needs and characteristics of the industry is a prerequisite for the formation of policy to regulate its foreign economic activity, taking into account the constraints imposed by the international environment, the interests of other industries and the ability of state institutions and civil servants to adopt and implement regulatory solutions.

The use of the approach, which can be conditionally called "industry-centric", necessitates the use to regulate the development of the industry not only general, but rather common tools that affect macroeconomic levers (inflation, exchange rate, income, market conditions, etc.) regardless sectoral needs, but also special, which affects the levers that are specific to each industry (the volume of public procurement, the level of taxation of innovation, technical standards, etc.).

It is obvious that taking into account the features, cement industry' needs and limitations cannot be done on a "general basis", as it is done today. The cement industry is one of the basic economy branches and, like many other industries (mining, coal, agriculture, etc.), needs special attention from the state. Failure to realize this fact is likely to mean the industry loss. These considerations necessitate the formation of a special component of regulatory tools, which should be aimed at specific point problems of foreign trade.

Having identified the problems of development of FEA of cement industry enterprises of Ukraine and taking into account the opinions of industry experts with the use of analytical hierarchy process, we can identify the most important priorities of state regulation and group them accordingly:

1. Sales: support for market restructuring; stimulating the diversification of the product range; struggle against unfair competition.

2. Institutional: streamlining the legislation on foreign economic activity by type of activity; creation of institutions to support foreign economic activity, in particular, the interaction of public authorities and the association of cement producers; financial support for export-import operations.

3. Instrumental: rationalization of a set of tools for the implementation of regulatory influence on FEA of cement industry enterprises.

Implementation of the proposed priorities of state regulation of FEA of cement industry enterprises should lead to the achievement of the following main goals:

- stimulating the increase of exports volumes and efficiency, as well as changes in its structure in favor of competitive products in the future;

- promoting the level of products international competitiveness through the introduction of innovations in their production;

- creating preconditions for the accumulation of investment funds by enterprises;

- encouraging enterprises to differentiate sources of investment;

- encouraging the search for alternative sources of attracting foreign investment for innovation and technological priorities (needs) of enterprise development;

- simplification of import procedures and minimization of tariff barriers to imports of fixed assets, the production of analogues of which is not established in Ukraine. 


\section{REFERENCES}

[1] B.S. Ahn. "The analytic hierarchy process with interval preference statements". Omega, vol. 67, pp. 177-185, 2017.

[2] O.A. Babak. "Features of legal responsibility in foreign economic activity". University Scientific Notes, vol. 3, pp. 149-154, 2009.

[3] A.P. Baskakov. "Formation of the organizational and economic mechanism for managing the foreign economic activity of industrial enterprises". Dissertation. Saratov State Socio-Economic University, 2006.

[4] P. Bozyk. "Globalization and the Transformation of Foreign Economic Policy". Burlingtion: Ashgate, 2006.

[5] R.A. Brand. "Fundamentals of International Business Transactions". The Hague, Kluwer Law International, 2000.

[6] M.M. Chanda, G. Bandyopadhyay and N. Banerjee. "Analysis and estimation of foreign exchange reserves of India using soft computing techniques". IIMB Management Review, vol. 32, pp. 280-290, 2020.

[7] Yu.O. Chugaenko. "Economic diplomacy in the system of management of foreign economic activity of the state". Actual problems of economy, vol. 3, pp. 59-69, 2013.

[8] J.D. Daniels and L.H. Radeba. "International business: external environment and business operations". 6th ed. Moscow: Delo Ltd, 1998.

[9] M. Davies and D.V. Snyder. "International Transactions in Goods: Global Sales in Comparative Context". New York: Oxford University Press, 2014.

[10] O.O. Demidyuk. "Improving the institutional efficiency of the economic system as a factor of sustainable development of Ukraine". Bulletin of Kyiv National University. Taras Shevchenko. Series: Economics, vol. 7 (160), pp. 27-33, 2014.

[11] A.F. De Toni, R.A. Franco, J. Li, Y. Li, G. Nassimbeni, M. Sartor, X. Zhao and X. Xu. "International Operations Management: Lessons in Global Business". Burlingnton: Gower Publishing Ltd, 2011.

[12] S.M. Dvyhun. "The content of public administration of foreign economic activity in the context of Ukraine's integration into the world economic space". Scientific Bulletin of Municipal Administration Academy. Series: Management, vol. 1, pp. 168-176, 2013.

[13] S.M. Frolov and O.I. Chobotar. "Instruments of covert protectionism and their influence on the regulation of foreign economic activity of Ukraine". Problems and prospects of development of the banking system of Ukraine, vol. 39, pp. 216-224, 2014.

[14] O.O. Grechyshkina and A.S. Kovalev. "Tax instruments for regulating foreign economic activity in Ukraine". Bulletin of the Volodymyr Dahl East Ukrainian National University, vol. 8 (215), pp. 26-29, 2014.

[15] E. Grešova, J. Svetlik. "Economic Impact of Industrial Segment in the Selected Country". Management Systems in Production Engineering, vol. 28 (4), pp. 312-317, 2020.

[16] R. Grosse and D. Kujawa. "International business. Theory and managerial applications". Boston: Irwin, 1992.

[17] A.M. Gud. "Structure and ways of modernization of nontariff regulation of foreign economic activity of enterprises in Ukraine". Customs, vol. 2, pp. 22-28, 2015.

[18] D.O. Hrytsychen and V.V. Nonik (Eds.) "Post-customs control in the security management system of foreign economic activity of the enterprise". Problems of theory and methodology of accounting, control and analysis. Series: Accounting, Control and Analysis, vol. 3, pp. 89-96, 2014.
[19] A. Ikenberry, D.A. Lake and M. Mastanduno. "The State and American Foreign Economic Policy". London, Ithaka: Cornell University Press, 1988.

[20] A. Klasen. "The Role of Export Credit Agencies in Global Trade". Global Policy, vol. 2, pp. 220-222, 2011.

[21] A.V. Kobylyanska. "Technical barriers to trade and foreign economic activity planning". Collection of scientific works of the Tavriya State Agrotechnological University (Economic Sciences), vol. 4, pp. 122-127, 2014.

[22] J.E. Leal. "AHP-express: A simplified version of the analytical hierarchy process method". MethodsX, vol. 7, 2020, 100748.

[23] N.I. Lipovska-Makovetska. "Improving customs and tariff regulation of foreign economic activity in Ukraine". Bulletin of Sumy National Agrarian University. Series: Economics and Management, vol. 5, pp. 169-172, 2013.

[24] A.O. Mashkov. "Improving the economic tools of state regulation of foreign economic activity". Economy and State, vol. 4, pp. 123-125, 2013.

[25] D.I. Minyuk. "Features of the objective elements of the composition of administrative offenses committed in the field of foreign economic activity". Law Forum, vol. 1, pp. 657-663, 2011.

[26] S.I. Mosiuk and I.P. Mosiuk. "Institutional principles of state regulation of economic activity". Scientific Bulletin of the National University of Life and Environmental Sciences of Ukraine. Series: Economics, Agrarian Management, Business, vol. 1 (200), pp. 244-248, 2014.

[27] D.C. North. (1981). "Structure and Change in Economic History". Cambridge: Cambridge University Press, 1981.

[28] V.V. Pasichnyk. "Characteristic features of permitting proceedings in the field of protection of economic competition in the implementation of foreign economic activity". Journal of Kyiv University of Law, vol. 3, pp. 153155, 2013.

[29] G.J. Plenert. "International Operations Management". Copenhagen: Business School Press, 2002.

[30] T. Pristai. "The range of authorized persons involved in the protection of the rights and legitimate interests of foreign economic activity". Bulletin of Lviv University. Series: Law, vol. 59, pp. 222-228, 2014.

[31] T.L. Saaty. "Decision making with the analytic hierarchy process". Int. J. Services Sciences, vol. 1 (1), pp. 83-98, 2008.

[32] T.L. Saaty. "Relative Measurement and its Generalization in Decision Making: Why Pairwise Comparisons are Central in Mathematics for the Measurement of Intangible Factors - The Analytic Hierarchy/Network Process". RACSAM (Review of the Royal Spanish Academy of Sciences, Series A, Mathematics): journal, vol. 2 (102), pp. 251-318, 2008.

[33] K. Schwab. (2018). The Global Competitiveness Report 2018. World Economic Forum. Available: http://www3.weforum.org/docs/GCR2018/05FullReport/ TheGlobalCompetitivenessReport2018.pdf [Mar. 11, 2021].

[34] G.J. Stigler. "The Theory of Economic Regulation". Bell Journal of Economics and Management Science, vol. 2, pp. 3-18, 1971.

[35] F.P. Tkachyk. and I.A. Hutsul. "Customs and tax regulators of foreign economic activity". Scientific notes of the National University "Ostroh Academy". Series: Economics, vol. 24, pp. 132-136, 2013.

[36] The Global Cement Report. 13th Edition. International Cement Review, 2020. 
[37] T. Topolnytska. (2020). "Ways of improving efficiency of regulation mechanism of foreign economic activity of Ukrainian cement industry enterprises". Efektyvna ekonomika 4.4 Available: http://www.economy.nayka.com.ua/?op=1\&z=7783 [Mar. 9, 2021].

[38] O.V. Trunova. (2013). "Application of the Saati method in making management decisions". Bulletin of Chernihiv National Pedagogical University. Pedagogical sciences 108.1. Available: http://www.irbis-nbuv.gov.ua/cgibin/irbis_nbuv/cgiirbis_64.exe?I21DBN=LINK\&P21DBN=U $J R N \& Z 21 \mid D=\& S 21 R E F=10 \& S 21 C N R=20 \& S 21 S T N=1 \& S 21 F$ MT=ASP_meta\&C21 [Mar. 11, 2021].

\section{Tetiana Topolnytska}

ORCID ID: 0000-0003-0125-542X

Ivano-Frankivsk National Technical University

of Oil and Gas

Department of Theory of Economics and Management Karpatska Street, 15, Ivano-Frankivsk, 76019, Ukraine e-mail: rtcb@ukr.net

\section{Romana Matskiv}

ORCID ID: 0000-0002-2966-6012

Ivano-Frankivsk National Technical University

of Oil and Gas

Department of Theory of Economics and Management Karpatska Street, 15, Ivano-Frankivsk, 76019, Ukraine e-mail: chrt50_32@ukr.net

\section{Oleh Yatsiuk}

ORCID ID: 0000-0002-3943-7352

Ivano-Frankivsk National Technical University

of Oil and Gas

Department of Theory of Economics and Management Karpatska Street, 15, Ivano-Frankivsk, 76019, Ukraine e-mail: olegstya@gmail.com

\section{Oksana Savko}

ORCID ID: 0000-0002-7282-7731

Ivano-Frankivsk National Technical University

of Oil and Gas

Department of Applied Economics

Karpatska Street, 15, Ivano-Frankivsk, 76019, Ukraine e-mail: oksana_savko19@ukr.net

\section{Bohdan Hryvnak}

ORCID ID: 0000-0002-4593-3862

Ivano-Frankivsk National Technical University

of Oil and Gas

Department of Social Sciences

Karpatska Street, 15, Ivano-Frankivsk, 76019, Ukraine

e-mail: gryvnak2906@gmail.com
[39] O.M. Vakulchik and I.D. Kharlamova. "Quantitative assessment of the qualitative characteristics of the subject of foreign economic activity in order to grant the status of an authorized economic operator". Bulletin of the Academy of Customs Service of Ukraine. Series: Economics, vol. 1, pp. 12-23, 2013.

[40] G. W. Veriha. "Currency market of Ukraine: problems and prospects of regulation". Donetsk: Knowledge (Donetsk branch), 2013.

[41] T.M. Vysotska. "The essence of economic and legal means of protection of foreign economic activity". Journal of Kyiv Law University, vol. 2, pp. 200-203, 2012.

[42] Ch. Wright. "Export Credit Agencies and Global Energy: Promoting National Exports in a Changing World". Global Policy, vol. 2, pp. 133-143, 2011. 